\title{
A recently developed approach in tumor therapy using Salmonella
}

\author{
Mahmoud Gharbavi ${ }^{1,5}$, Giti Karimkhanlooei ${ }^{2}$, JAFar AMANI ${ }^{3}$, Pardis Kashiazari ${ }^{4}$, Ali Sharafi ${ }^{5}$ * \\ ${ }^{1}$ Department of Pharmaceutical Biomaterials, School of Pharmacy, Zanjan University of Medical Sciences, Zanjan, Iran \\ ${ }^{2}$ School of Medicine, Zanjan University of Medical Sciences, Zanjan, Iran \\ ${ }^{3}$ Applied Microbiology Research Center, Baqiyatallah University of Medical Sciences, Tehran, Iran \\ ${ }^{4}$ Department of Biology, Payame Noor University, Khoy, Iran \\ ${ }^{5}$ Zanjan Pharmaceutical Biotechnology Research Center, Zanjan University of Medical Sciences, Zanjan, Iran
}

\begin{abstract}
There are three main approaches in cancer treatment: surgery, chemotherapy, and radiotherapy. Recently, the use of bioengineered bacteria as therapeutic agents has been shown to have some valuable properties in the treatment of cancer, which do not exist in conventional approaches. Bacteria in particular can target tumors, and they can preferentially proliferate and accumulate within tumors and inhibit the growth of cancer cells by inducing cytotoxicity. Thus, bacteria can be easily detected in tumor sites. Moreover, bacteria-derived factors exert an immunostimulatory effect. Over the past decade, Salmonella, Clostridium, and other bacterial genera have been shown to inhibit tumor growth and promote the survival rate in animal models. Clinical trials for cancer treatment with bacteria have shown improved results by combination with other therapeutic methods such as chemotherapy or radioactive agents. This review is an effort to introduce the use of healthy bacteria in tumor therapy. We specifically focus on Salmonella, which has been extensively used in tumor therapy. Therefore, in this review study, we discuss the merits, mechanisms, and attenuated strains of a combination therapy compared to other therapeutic approaches in Salmonella-mediated cancer therapy.
\end{abstract}

Key words: cancer therapy, combination therapy, Salmonella, tumor targeting

\section{Abbreviations}

$\begin{array}{ll}\text { AB } & \text { - antibodies } \\ \text { TAR } & \text { - aAspartate receptors } \\ \text { Baf A1 } & \text { - bafilomycin A1 } \\ \text { BCR } & \text { - B-cell receptor } \\ \text { BCRP } & \text { - breast cancer resistance protein } \\ \text { Dcs } & \text { - dendritic cells } \\ \text { IgM } & \text { - immunoglobulin M } \\ \text { IFN- } \gamma & \text { - interferon-gamma } \\ \text { IL-1 } \beta & \text { - interlukin-1 } \beta \\ \text { LPS } & \text { - lipopolysaccharide } \\ \text { LTA } & \text { - lipoteichoic acid } \\ \text { MHC-II } & \text { - major histocompatibility class II } \\ \text { MAPK } & \text { - mitogen-activated protein kinase } \\ \text { MDR1 } & \text { - multidrug resistance mutation } 1\end{array}$

$\begin{array}{ll}\text { MRP1 } & \text { - multidrug resistance protein } 1 \\ \text { NK } & \text { - natural killer } \\ \text { NF-אB } & \text { - nuclear factor-kb } \\ \text { Nod } & \text { - nucleotide oligomerization domain } \\ \text { NLRs } & \text { - nod-like receptors } \\ \text { PAMPs } & \text { - pathogen-associated molecular patterns } \\ \text { PRRs } & \text { - pattern recognition receptors } \\ \text { TRG } & \text { - ribose/galactose receptor } \\ \text { SCV } & \text { - Salmonella -containing vacuole } \\ \text { Th1 } & \text { - T helper } 1 \\ \text { TLRs } & \text { - toll-like receptors } \\ \text { TNF- } \alpha & \text { - tumor necrosis factor-alpha } \\ \text { TNFSF14 } & \text { - tumor necrosis factor superfamily member } 14 \\ \text { T3SS } & \text { - type III secretion system }\end{array}$

\footnotetext{
* Corresponding author: Zanjan Pharmaceutical Biotechnology Research Center, Zanjan University of Medical Sciences, Zanjan, Iran; e-mail: sharafi.a@gmail.com
} 


\section{Introduction}

Cancer has been one of the leading causes of morbidity and mortality for decades (Kural-Seyahi et al., 2003; Resnick et al., 2012). Cancer therapies are limited to surgical removal, radiation, chemotherapy, and immunotherapy (Perry et al., 1987). These methods encounter problems such as drug resistance, pharmacological or toxicity concerns in a majority of cases, and a risk of damage to healthy tissues or incomplete eradication of cancer (Mukherjee et al., 2016). Unfortunately, the nonspecific targeting of anticancer agents leads to many side effects, and the poor drug delivery fails to produce the desired outcome in several cases (Brigger et al., 2012, Bahrami et al., 2017). The major challenge in cancer therapy is to differentiate between cancerous and normal body cells. To address this problem, researchers have devoted considerable efforts to engineer drugs to provide more efficient treatments, which can potentially detect cancer cells and prevent their growth by inhibiting proliferation (Hare et al., 2017). Chemotherapy, radiotherapy, and surgery are currently used in cancer treatment, despite the fact that they have several disadvantages. For example, cancer patients do not usually respond to the single-agent chemotherapy regimen and are therefore switched to multi-agent chemotherapy regimens, which in turn increase both side effects and toxicity (Bower et al., 1997, Lurain and Nejad, 2005). In addition, drug resistance (King and Jarvis, 2007), damage to healthy cells (Lushbaugh and Casarett, 1976), or hypopituitarism (Melmed et al., 2009) occur in conventional cancer therapy. On the other hand, a nanotechnology approach seems to be extremely valuable in cancer therapy and offers considerable advantages such as effective prevention tools, more reliable diagnostics, considerable imaging techniques, efficient cancer cell targeting, and improvement in the quality of life throughout cancer care period (Gharbavi et al., 2018; Gharbavi et al., 2019; Gharbavi et al., 2020).

The pathophysiological changes in diseased tissues may improve vascular permeability along with impaired lymphatic drainage in tumors that allows an enhanced permeability and retention effect of nanoparticles in tumors (Maeda al., 2000; Sahoo et al., 2007; Parveen et al., 2007). One of the most critical obstacles of nanoparticle use in cancer treatment is variations in particle size used in the nanoscale materials, which can induce extensively diverse changes in their properties, including toxicity (Xia etal., 2006; Boverhof andDavid, 2010).

In general, three different areas can be distinguished in tumor sites: area with epithelial tumor cells, hypoxic area, and necrotic area, as shown in Figure 1. Radiotherapy uses ionizing radiation to irradiate tumor cells, which causes DNA damage in the cells and controls their proliferation. Ionizing radiation causes the formation of free radicals in cells, which subsequently results in cancer cell death (Patriciu et al., 2007). Ionizing radiation does not precisely discriminate between tumor and healthy cells; hence, radiotoxicity to healthy tissues is considered as one of the critical limiting factors in cancer treatment by radiotherapy (Hainfeld et al., 2008, Paulides et al., 2013). Additionally, many clinical studies indicate that due to poor vascularization, the hypoxic and necrotic tumor regions are more resistant to ionizing radiation, which is considered as another major drawback of tumor therapy (Yan et al., 2020).

Chemotherapy is one of the most commonly used strategies in cancer therapy, but some of its drawbacks often limit its efficacy (Jahandideh et al., 2017). Two main processes limit the efficiency of chemotherapy: first, the expression of genes involved in drug resistance, such as MDR1 (multidrug resistance mutation 1), MRP1 (multidrug resistance protein 1), and BCRP (breast cancer resistance protein) (Efferth et al., 2003; Wu et al., 2014); second, hypoxic tumor regions are resistant to chemotherapy because of their distance from the vasculature, which leads to poor drug delivery and eventually results in anticancer drug resistance.

Because of these drawbacks, radio-chemotherapy is not efficient in cancer treatment. Cancer therapy using bacteria is a promising method in addressing such pressing problems. It has already been reported 200 years ago that cancer patients were in remission after being infected with bacteria (Morrissey et al., 2010). Between 1890 and 1930, William B. Coley, an American physician, conducted a set of experiments to treat cancer patients by using bacteria such as Streptococcus pyogenes, Serratia marcescens, and bacterial products, termed "Coley's vaccine" or "Coley's toxin." Coley believed that "the toxin" from dead cells of Streptococcus pyogenes and Serratia marcescens were capable of stimulating immune system response to fight cancer. In 1962, Coley's toxin for cancer treatment was banned, but pre- 


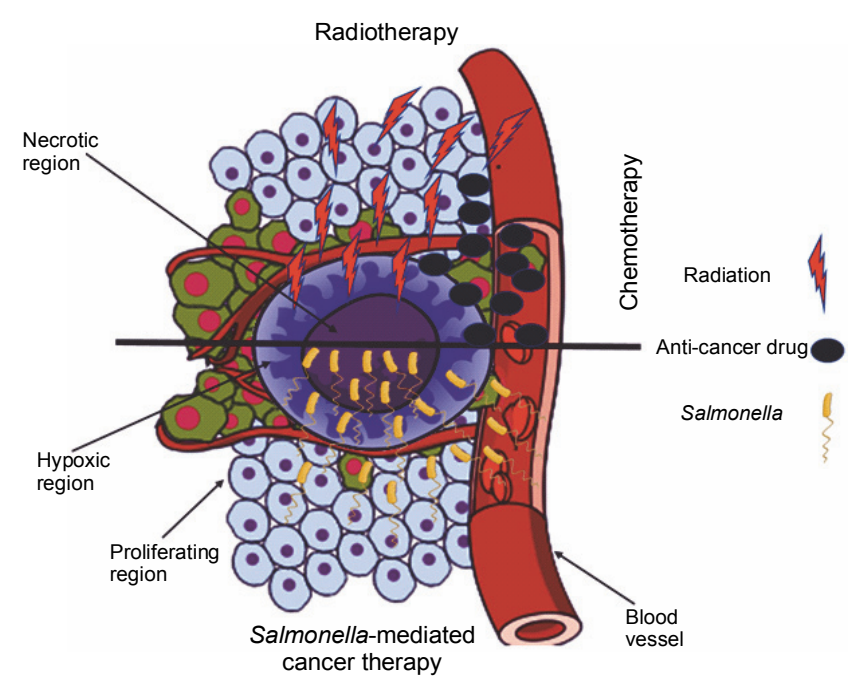

Fig. 1. Schematic representation of the mechanisms underlying the therapeutic effects of different cancer therapies (chemotherapy, radiotherapy, and Salmonella-mediated cancer therapy)

sently, bacteriotherapy is considered a novel therapy (Goodman and Walsh, 2001; Bandura, 2017). In this procedure, bacteria are used as anticancer agents with many advantages prominently in terms of their genes that can easily be manipulated. Additionally, bacteria can be engineered to overcome the drawbacks of conventional cancer therapy (radiation and chemotherapy) (Minton, 2003; Felgner et al., 2016; Hill et al., 2016; Nguyen and Min, 2017).

Compared with the previously applied cancer therapy methods, bacteriotherapy is one of the recent methods that has several advantages, including the oral administration route (Levine et al., 1987; Clairmont et al., 2000), high proliferative capacity without adopting external agents (Pawelek et al., 1997), extendibility of the therapeutic effect, sufficient tissue penetration, and the flexibility of delivery along with facilitation of host's immune response (Juris et al., 2002).

This method can also be combined with other therapeutic methods such as chemotherapeutic drugs (Mercado-Lubo et al., 2016; Yang et al., 2018), radiotherapy, and noninvasive monitoring techniques (Jiang et al., 2010; Barker et al., 2015). Neil S. Forbes, in a review article, stated that bacteria are tiny programmable "robot factories," which can be directed to tumor cells (Forbes, 2010). The accumulation of bacteria in tumor cells is approximately 1000 -fold higher than that in healthy cells, and these agents induce severe toxicity in cancer cells (Maeda, 2012).

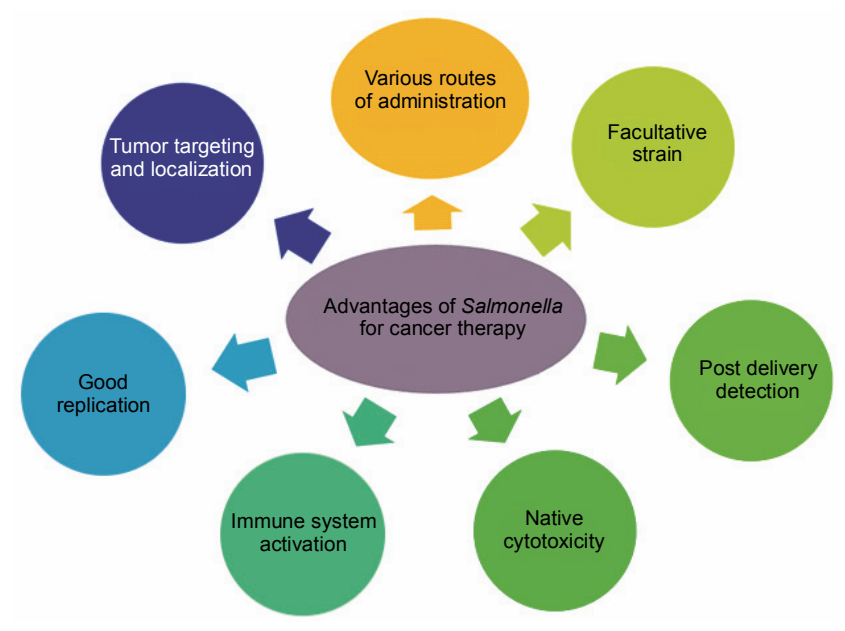

Fig. 2. Advantages of Salmonella as an antitumor agent

Several types of bacteria (anaerobes and facultative anaerobes) have been used in animal models or human clinical trials to treat tumor cells by destruction (Zhao et al., 2005; Arrach et al., 2008; Arrach et al., 2010; Taniguchi et al., 2010; Leschner et al., 2012). General tumor treatment strategies, including chemotherapy, radiotherapy, and Salmonella therapy, are schematically shown in Figure 1. Facultative anaerobic bacteria such as Salmonella, Escherichia, Shigella, Vibrio, and Listeria are used owing to their ability to target and colonize vasculature and hypoxic tumor regions (Ryan et al., 2006).

\section{Salmonella as an antitumor agent}

Several bacterial species such as Salmonella, Clostridium, Escherichia, and Bifidobacterium have been used as anticancer agents (Pawelek et al., 2003; Ryan et al., 2006; Theys et al., 2006; Van Mellaert et al., 2006; Chen et al., 2009; Kimura et al., 2010; Leschner and Weiss, 2010).

Evidence shows that Salmonella and Clostridium have been used successfully for treatment purposes (Dang et al., 2001; Cheong et al., 2006; McCarthy, 2006; Wei et al., 2007).

Importantly, although the aforementioned pathogens have been directly used in animal models, live genetically modified organisms have been conventionally used in human trials (Toso et al., 2002; Heimann and Rosenberg, 2003). Given that Bifidobacterium, Clostridium, and Salmonella are obligate anaerobes and colonize the areas devoid of oxygen, they must be injected into solid tumors in a spore form to preferentially target and 
replicate in the hypoxic/necrotic regions (Xu et al., 2009; Liu et al., 2014).

Given that Salmonella has several potential advantages (as presented in Fig. 2) in therapeutic tumor targeting, genetic modifications have been introduced to improve its tumor-targeting or tumor therapy. As such, some Salmonella strains, including YB1, VNP20009, and $S L 7207$, have been genetically modified to preferentially target and replicate in the hypoxic and necrotic regions of tumors and therefore inhibit tumor growth (Heimann and Rosenberg, 2003; Yu et al., 2012).

Some of the main characteristics of Salmonella are indicated below:

- Salmonella is a facultative anaerobic strain with the potential to grow regardless of oxygen presence and can colonize vasculature and hypoxic tumor regions (Nguyen et al., 2010; Guo et al., 2011; Li et al., 2012; Hong et al., 2013; Jeong et al., 2014).

- Several routes of administration have been reported for Salmonella delivery as an anticancer agent, such as intravenous (IV), intraperitoneal (IP), intratumoral, and oral (Urashima et al., 2000; Zhang et al., 2007; Yang et al., 2008; Ganai et al., 2009).

- Tumor-targeting ability of Salmonella has enabled it to play a significant therapeutic role in solid tumor treatment such as therapies related to colon (Nguyen et al., 2010; Guo et al., 2011; Hong et al., 2013; Jeong et al., 2014), fibrosarcoma (Roider et al., 2011), bladder (Iyer et al., 2016; Koshiol et al., 2016; Vagholkar et al., 2016), liver (Nguyen et al., 2010; Hartono et al., 2012; Koshiol et al., 2016), pancreas (Felgner et al., 2016), lung (Lee et al., 2005), melanoma (Lee et al., 2005; Chen et al., 2012; Kaimala et al., 2014), breast (Ganai et al., 2009), and prostate cancers (Chen et al., 2012).

- Salmonella and its derivatives prefer solid tumors to normal tissue; they are located or they can be localized specifically at tumor sites, which helps to reduce toxic side effects of systemic delivery (Kasinskas and Forbes, 2006, 2007).

- Unlike other bacteria, Salmonella has a high rate of replication at tumor sites, thus requiring a low dose to effectively target tumors (Lee et al., 2005; Roider et al., 2011).

- Salmonella has the potential for metabolic activation and is capable of continuous production of cytolysin A to attack tumors, which can lead to improvement in delivery efficiency (Chen et al., 2012; Kaimala et al., 2014).

- Immune system activation: Salmonella bound to nucleotide oligomerization domain (Nod)-like receptors (NLRs) induces the activation of caspase- 1 and subsequent secretion of proinflammatory cytokines such as IL-1 $1 \beta$, IL-18, TNF- $\alpha$, and IFN- $\gamma$ as well as pyroptosis (inflammatory cell death).

- This leads to improvement of the immunosuppressive conditions and helps to maintain an innate adaptive response (de Zoete and Flavell, 2013; Perez-Lopez et al., 2013).
- Self-relied cytotoxicity: the natural toxicity of bacteria capable of producing virulence factors leads to the sensitization of the immune system along with neutrophil infiltration and antitumor immune responses (Sznol et al., 2000; Hoffman and Zhao, 2006; Lee et al., 2008).

- Post-delivery functionality: four different strategies are used to identify bacteria in tumors, including bioluminescence, fluorescence, magnetic resonance, and positron emission imaging (Urashima et al., 2000; Soghomonyan et al., 2005; Hoffman and Zhao, 2006; Steele-Mortimer, 2008).

\section{Salmonella-mediated tumor therapy}

\section{Distribution of Salmonella in host cells}

Salmonella embodies a bacterial system that invades nonphagocytic cells by modulation. In cancer therapy, Salmonella can potentially enter the cells through both Trigger and Zipper processes (Velge et al., 2012). In the Zipper mechanism, the Rck protein is expressed on Salmonella's outer cell membrane and interacts with its receptor on the host cell membrane, which leads to phosphorylation of at least one tyrosine kinase. The activation of class I PI 3-kinase leads to the activation of protein kinase $\mathrm{B}$ (aka Akt). The activation of the guanosine triphosphatase protein (GTPase) Rac1, the downstream molecule of the Akt/PI 3-kinase activation, and the GTPase Cdc42 trigger actin polymerization via the Arp2/3 complex (Mijouin et al. 2012).

The mechanism controlling Cdc42 during the Rckinduced signaling pathway is still unknown (Mijouin et al., 2012; Velge et al., 2012; Wiedemann et al., 2012). However, several studies have demonstrated that Salmonella invades host cells only via the Trigger entry mechanism (Stender et al., 2000; Steele Mortimer, 2011; Cossart and Helenius, 2014).

In the Trigger mechanism, Salmonella bacterial effectors, including SipA, SipC, SopB, SopE, SopE2, which are induced by type III secretion system (T3SS), are directly injected into host cells. While SipA and SipC directly bind to actin, SopE, SopE2, and SopB activate the Rho GTPases, leading to host cell cytoskeleton remodeling via cellular proteins, such as WASP/Scar/ WAVE/WASH, which activate the Arp2/3 complex. Thus, the formation of membrane ruffles and internalization is induced by the recruitment of the exocyst complex and is manipulated by $\mathrm{SipC}$ and SopE via the Ras-related protein RalA (Chen et al., 1996; Schlumberger and Hardt, 2006). Following the entry into the host cells, Sal- 


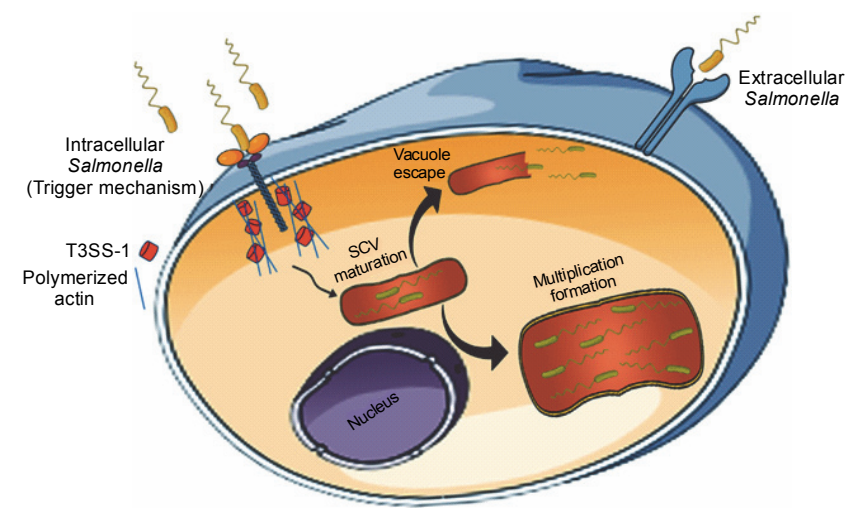

Fig. 3. Intracellular Salmonella invades nonphagocytic host cells through the Trigger mechanism

monella replicates within a membrane-bound compartment termed Salmonella-containing vacuole (SCV).

Previous studies have shown that SifA, SseF, and SseG are involved in the formation of Salmonella-induced filaments (Sifs) that are required for maintaining the SCV (Salcedo and Holden, 2003; Boucrot et al., 2005; Abrahams and Hensel, 2006). After formation, the $\mathrm{SCV}$ proceeds to maturation and mediates the virulent factors for secretion into the cytoplasm. This process also facilitates the delivery of nutrients to SCV and leads to Salmonella replication and SCV-lysosome fusion (the autophagy response), wherein the bacterial cells are likely to disappear. As shown in Figure 3, a segment of bacteria can be released from the SCV that efficiently target the cytosol of epithelial cells.

\section{Targeting the components of cancer cells}

The main vague point about Salmonella is specifically the way it migrates to the tumor region. Several studies have described the interaction of Salmonella and tumor aggregates by using 3D cell culture chip (Barrila et al., 2010; Ravi et al., 2017). As previously reported, Salmonella preferentially accumulates in internal tumor region boundaries and can directly destroy tumor cells (Rosenberg et al., 2002; Yu et al., 2012).

Flagella are surface appendages of Salmonella and play a critical role in the interaction of Salmonella with host cells through multiple functions such as motility and chemotaxis, leading to the attraction of Salmonella in the tumor microenvironment structure by increasing the likelihood of contact (Jones et al., 1992; Dang et al., 2001). For example, aspartate receptors (TAR) on the Salmonella surface detect the aspartate secreted by the existing cancer cells through chemotaxis transmitted to tumor cells. Ribose/galactose receptor (TRG) also supports transmitting Salmonella to necrotic tissue (Kasinskas and Forbes, 2006; Kasinskas and Forbes, 2007).

Several interacting mechanisms are used to control tumor accumulation; as Salmonella surrounds the chaotic vasculature of tumors (Forbes et al., 2003), it allows for a tremendous influx of blood into tumors and promotes inflammation (Leschner et al., 2009), transmits chemotaxis towards tumors compounds, (Kasinskas and Forbes, 2006, 2007) and finally, enables preferential antitumor replication in tumor-specific microenvironment scales (Nuyts et al., 2001; Forbes et al., 2003; Kasinskas and Forbes, 2006) as well as clearance protection initiated by the immune system (Sznol et al., 2000).

These mechanisms enable Salmonella to accumulate in tumor sites at ratios higher than 1000/1 compared to other organs such as the liver and spleen. Bacterial growth in tumor tissues causes nutrient depletion in cancer cells and induces antitumor immune response, leading to tumor cell death (Sznol et al., 2000).

\section{Salmonella and the immune system}

\section{Interaction of Salmonella with macrophages}

Tumors limit the maturation and infiltration of the immune cells, which results in immunosuppression and exclusion from the immune system tracking (Sznol et al., 2000). As mentioned before, Salmonella can survive and proliferate intracellularly via SCV, especially in macrophages.

Microbial products, termed pathogen-associated molecular patterns (PAMPs), include lipopolysaccharides, flagella, and peptidoglycans, which are strong agonists for pattern recognition receptors (PRRs) such as Toll-like receptors (TLRs), especially TLR-4 and TLR-5 (Sfondrini et al., 2006; Lee et al., 2008), scavenger receptors, mannose receptors, and NOD-like receptors (NLRs).

Macrophages have the potential of recognizing microbial products via PRRs and transducing signals through NF- $\mathrm{KB}$ or MAPK, which consequently leads to a proinflammatory effect, and cytokines through consistent and adaptive immune responses. In addition, Salmonella is capable of inducing continuous signals with effectors secreted by T3SS (Bruno et al., 2009). One of the most common questions that can be asked is how, despite the 
presence of a host immune system, does Salmonella evade the tumor cells? Indeed, Salmonella can utilize several strategies.

One of the strategies used is the prevention of dendritic cells (DCs) from activating antigen-specific $T$ cells. This may be achieved in two ways: Firstly, preventing SCV acidification with Bafilomycin A1 (Baf A1) causes a significant decrease in the frequency of persisters (Helaine et al., 2014). Secondly, Salmonella is capable of inducing macrophage death in a caspase 1-dependent manner. Salmonella-mediated NLRC4 and NLRP3 can activate caspase 1, which then initiates a proinflammatory cell death termed pyroptosis, leading to the modulation of the macrophage function (Mazurkiewicz et al., 2008; Figueira and Holden, 2012). Salmonella also has the capacity to escape the immune system via the secretion of sipB protein and can induce dendritic cell death in a caspase 1-dependent manner, thus impairing the antigen presenting process and the adaptive immunity (Halici et al., 2008). Furthermore, Salmonella can induce ubiquitination of major histocompatibility class II complex (MHC-II) by T3SS effectors such as ssaV and can cause subsequent removal of the mature MHC-II-peptide complex from the cell surface, which then leads to the modulation of DC function (Halici et al., 2008).

Salmonella Pathogenicity Island 1 (SPI-1), which promotes the phagocytosis of bacteria in nonphagocytic cells, can suppress this process in DCs in a phosphatidylinositol 3-kinase (PI3K)-dependent manner (Bueno et al., 2010; Oppong et al., 2013).

\section{Interaction of Salmonella with B cells}

Host B cells are necessary for the antitumor activity to help Salmonella by controlling their distribution around the tumor region. In this sense, the B-cell receptor (BCR) is composed of immunoglobulin molecules that form a type 1 transmembrane receptor protein usually located on the outer surface of a lymphocyte type known as B cells (Fahy et al., 2004; Westphal et al., 2008; Lee et al., 2011).

Bacteria are recognized by the $\mathrm{BCR}$ and induce $\mathrm{Sal}$ monella internalization followed by B cell differentiation (variation) and secretion of anti-Salmonella antibodies (AB) by Salmonella-specific B cells (Anuforom, 2015).

Antibodies produced by B cells lead not only to a slightly lower quantity of bacteria in the tumor sites but also to a decrease in inflammation and cytokine production in the intact organs after systemic Salmonella treatment (Maaser et al., 2004). Furthermore, B cells regulate the proliferation of Salmonella-specific CD4+ T cells, which enhance Salmonella-specific production of AB (Alaniz et al., 2006).

Therefore, after the administration of Salmonella, their exit from tumor cells is very slow as compared to that from other organs such as liver and spleen, which are under constant surveillance by the host immune system. B cells specify the dissemination of Salmonella in tumor organs and prevent their spread to the healthy organs. Anti-Salmonella IgM antibodies are present in tumor microenvironment (Barr et al., 2009).

\section{Interaction of Salmonella with $T$ cells}

Salmonella, which has been shown to cause T-cell activation, induces response of both anti-Salmonella-specific and tumor antigen-specific and expression of Connexin 43 as a gap junction protein induced by lipopolysaccharide (LPS), lipoteichoic acid (LTA), and flagellin of bacteria (Maybeno et al., 2012).

This protein also creates junctions through melanoma cancer cells to immune dendritic cells. As a result, the dendritic cells use the protein transferred from the tumor cells to $\mathrm{T}$ cells in order to stimulate the T-cell response, subsequently leading to target and cleanse the tumor cells at the affected site. Consequently, Salmonella inhibits tumor growth by utilizing $\mathrm{T}$ cells.

On the other hand, the cross-presentation of tumor antigen increases the infiltration of CD8+ T cells in Salmonella-treated tumors and enhances the immune system response (Avogadri et al., 2005). Such responses, while enhancing the antitumor efficacy of Salmonella expressing cytokines, also increase immunity and prevent tumor growth (Fig. 4) (Sorenson et al., 2008).

\section{Interaction of Salmonella with cytokines}

Salmonella infection usually induces both antigenrecognizing $\mathrm{T}$ and $\mathrm{B}$ cells to mediate immunity that leads to the inhibition of tumor growth and metastasis. In such situations, the levels of circulating and hepatic natural killer (NK) cells, hepatic CD4+, and CD8+ T lymphocytes, splenic neutrophils, and macrophages are increased (Mittrücker and Kaufmann, 2000; Feltis et al., 2002). The expression of cytokines such as TNF- $\alpha$, IFN- $\gamma$, IL-1, IL-6, IL-12, and IL-18 is subsequently eleva- 


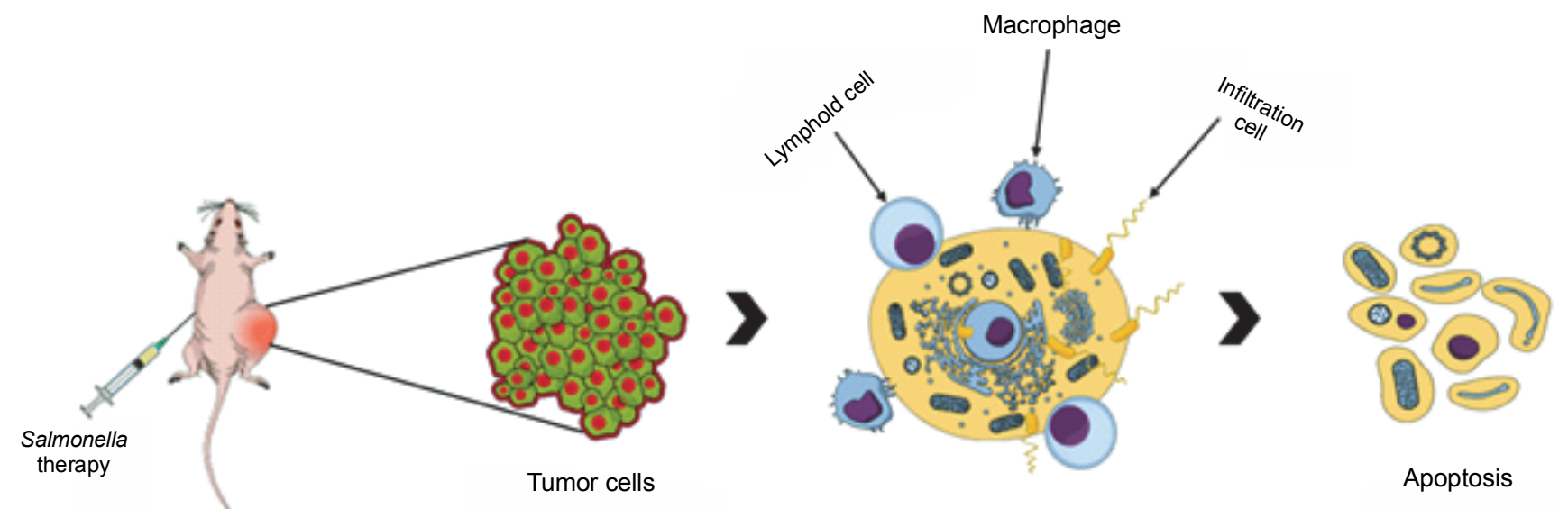

Fig. 4. Salmonella-mediated cell death pathway in tumor cells

ted, modulating the immune response and resulting in the inhibition of tumor growth (Weiss et al., 2007).

In addition, Salmonella can be engineered to deliver cytokines such as IL-2, IL-18, CCL21, and LIGHT, which exert antitumor effects (Forbes, 2010). Cytokines stimulate the immune cells to inhibit tumor growth by utilizing multiple mechanisms such as the upregulation, proliferation, and migration of immune cells (Marcus et al., 2014).

IL-2 is a signaling molecule that activates the proliferation of $\mathrm{B}$ cells and $\mathrm{T}$ cells and the cytolytic function of cleansing, which leads to a reduction in angiogenesis, increases necrosis within tumor tissues, and finally, prevents tumor formation (Feltis et al., 2002; Barbé et al., 2005).

IL-18 is produced mainly by activated monocytes, macrophages, and DCs. It has several immunoregulatory functions such as generating IFN- $\gamma$ from $\mathrm{NK}$ and Thelper 1 (Th1) cells, thereby enhancing the cytolytic activity of $T$ cells by generating cytotoxicity of NK cells and upregulating MHC class I antigen expression that promotes the differentiation of $\mathrm{CD} 4+$ helper T cells into Th1 cells and suppresses angiogenesis by inhibiting the proliferation of endothelial cells. Thus, NK cells, macrophages, and CD8+ T cells mediate the antitumor effects (Gracie et al., 2003; Raupach et al., 2006; Loeffler et al., 2008).

The activities of CCL21 suggest that the effective control in terms of the dynamics of lymphocytes, DCs, and NK cells can possibly impede tumor-induced immunosuppression, thereby optimizing effective immune responses and subsequently resulting in tumor suppression (Loeffler et al., 2009). In addition, CCL21 appears to be involved in antitumor functionality through the binding of the chemokine receptor CXCR3 (Maekawa et al., 2008).

LIGHT, also known as tumor necrosis factor superfamily member 14 (TNFSF14), is a cytokine from the TNF family that is homologous to lymphotoxin that stimulates the proliferation of $\mathrm{T}$ cells, induces $\mathrm{DC}$ growth and triggers tumor cell apoptosis, thereby leading to tumor suppression (Glenney and Wiens, 2007; Loeffler et al., 2007). IFN- $\gamma$ (type II interferon) is an important activator of macrophages and stimulates the expression of MHC I and MHC II molecules. It exerts antitumor effects through two mechanisms: preventing tumor cell growth and indirectly stimulating the adaptive immune system response (Böhm et al., 1998). In addition, IFN- $\gamma$ produces antiangiogenic chemokines, including protein-10 and monokines, through the development of IFN- $\gamma$-dependent CD4+ T cells, which enhance the growth of angiogenesis-dependent tumor (Qin and Blankenstein, 2000).

\section{Attenuated Salmonella strain as an antitumor agent}

To treat cancer, Salmonella cells have been extensively studied as antitumor agents. Decades ago, many antitumor features of Salmonella were demonstrated (Chorobik et al., 2013), and several attenuated Salmonella strains were developed for tumor-targeting studies as presented in Table 1.

\section{Live genetically modified Salmonella typhimurium (VNP20009)}

VNP20009 has been derived from Salmonella typhimurium ATCC 14028 that contains most of the characteristics of Salmonella (Broadway et al., 2017) and has 
Table 1. Attenuated Salmonella strains for targeted cancer therapy

\begin{tabular}{|c|c|c|c|}
\hline Strains & Genotype & Description & References \\
\hline VNP20009 & $\Delta m s b, \Delta p u r I$ & $\begin{array}{l}\text { purine auxotrophic mutation } \\
\text { and modified lipid A }\end{array}$ & $\begin{array}{l}\text { Toso, Gill et al., 2002; Heimann, Rosenberg, 2003; Nemunaitis, } \\
\text { Cunningham et al., 2003; Thamm, Kurzman et al., 2005; Wang, Chen } \\
\text { et al., 2013; Coutermarsh-Ott, Broadway et al., } 2017\end{array}$ \\
\hline$A 1-R$ & $\begin{array}{l}\text { leucine } \\
\text { and arginine auxotrophs }\end{array}$ & leucine/arginine-dependent & $\begin{array}{l}\text { Zhao, Yang et al., 2005; Zhao, Yang et al., 2006; Zhao, Geller et al. } \\
\text { 2007; Momiyama, Zhao et al., 2012; Yano, Zhang et al., } 2014\end{array}$ \\
\hline CRC2631 & wild-type & decreasing the amount of available wild-type lipopolysaccharide (LPS) & Kazmierczak, Gentry et al. 2016 \\
\hline$\Delta p p G p p$ & $\Delta$ relA, $\Delta$ spoT & defective in ppGpp synthesis; noninvasive to mammalian cells & Nguyen, Kim et al., 2010; Jiang, Park et al., 2013; Kim, Phan et al., 2015 \\
\hline$S L 3261$ & $\Delta \operatorname{aroA}$ & blocked in aromatic synthesis & Lin, Kao et al., 2012; Ye, Li et al., 2013 \\
\hline$S L 1344$ & wild-type & virulent laboratory strain (hisG mutant of wild-type 4/74) & Roider, Jellbauer et al., 2011 \\
\hline$S A 186$ & $\triangle$ znuABC & $\begin{array}{l}\text { deletion of the whole znuABC operon, } \\
\text { which encodes the high-affinity zinc transporter }\end{array}$ & Chirullo, Ammendola et al., 2015 \\
\hline NCTC12023 & wild-type & isogenic to ATCC 14028 & Xiong, Husseiny et al., 2010 \\
\hline SL7207 & $\Delta \operatorname{aroA}$ & $\begin{array}{l}\text { aromatic amino acid synthesis depends } \\
\text { on } p \text {-aminobenzoate and } 2,3 \text {-dihydroxybenzoate }\end{array}$ & $\begin{array}{l}\text { Berger, Soldati et al., 2013; Jarosz, Jazowiecka-Rakus et al., 2013; Li, } \\
\text { Yin et al., 2013; Shi, Yu et al., } 2016\end{array}$ \\
\hline LH340 & $\Delta \mathrm{phoP}, \Delta \mathrm{phoQ}$ & $\begin{array}{l}\text { cytoplasmic transcriptional regulator }(\mathrm{PhoP}) \\
\text { and membrane-associated sensor kinase }(\mathrm{PhoQ})\end{array}$ & $\begin{array}{l}\text { Zhang, Gao et al., 2007; Jia, Li et al., 2012; Jarosz, Jazowiecka-Rakus } \\
\text { et al., } 2013\end{array}$ \\
\hline BRD509 & $\Delta \operatorname{aroA}, \Delta \operatorname{aroD}$ & aromatic compound-dependent & Al-Ramadi, Fernandez-Cabezudo et al., 2009; Yoon, Choi et al., 2014 \\
\hline S634 & $\Delta \operatorname{aroA}$ & aroA mutation and modified lipid A & Lee, Wu et al. 2004 \\
\hline LVR01 & $\Delta \operatorname{aroC}$ & auxotrophic for certain aromatic compounds & Grille, Moreno et al. 2014 \\
\hline YB1 & $\Delta \operatorname{aroA}$ & $\begin{array}{l}\text { engineered to express the essential asd gene } \\
\text { under the control of a hypoxia-inducible promoter }\end{array}$ & Yu, Shi et al. 2015 \\
\hline RE88 & $\Delta \operatorname{aroA}, \Delta$ dam & $\begin{array}{l}\text { defective in DNA adenine methylase; fails to secrete the protein; } \\
\text { noninvasive to mammalian cells }\end{array}$ & $\begin{array}{l}\text { Xiang, Mizutani et al., 2005; Lee, Mizutani et al., 2006; Qian, Yan et } \\
\text { al. } 2011\end{array}$ \\
\hline SB824 & $\Delta$ aroA, $\Delta$ sptP & reduction of virulent gene expression & Roider, Jellbauer et al. 2011 \\
\hline MvP728 & $\Delta$ purD, $\Delta$ htrA & adenine-dependent; unable to survive in macrophages & Manuel, Blache et al., 2011; Xu, Hegazy et al., 2014 \\
\hline
\end{tabular}


been intensively investigated for its use in tumor therapy (Felgner et al., 2016). VNP20009 is a genetically modified strain of S. typhimurium that has several advantages such as an excellent safety profile, including $m s b B$ (lipid A biosynthesis myristoyl transferase) gene deletion, antibiotic susceptibility, and purI gene deletion to improve tumorspecific colonization (Clairmont et al., 2000).

VNP20009 growth depends on the level of purine, and it prefers to bind in purine-rich regions, can easily proliferate in these regions, and can be used for tumor tissue colonization. VNP20009 has been proven to be a promising tumor-target vector that can preferentially accumulate and replicate in a tumor tissue for tumor therapy (Thamm et al., 2005; Ganai et al., 2009; Loeffler et al., 2009; Wang et al., 2013).

\section{Conclusions}

Several researchers have found that Salmonella-mediated antitumor therapy is a promising therapeutic method that could potentially promote significant tumor suppression and thus prolong survival. Salmonellamediated antitumor therapy has some advantages over other therapies, such as bacterial proliferation, selftargeting, and easy genetic manipulation. In addition, Salmonella has multifaceted interplay between the upregulation of immunomodulatory molecules and the downregulation of aggressive phenotype-related proteins to counteract various protumor cellular processes. These characteristics make Salmonella an ideal candidate for anticancer therapy.

Moreover, Salmonella can be used to improve the survival of cancer patients or can be successfully used to improve the outcomes of the existing treatment strategies.

Most of the problems arising from the use of Salmonella, such as its potential toxicity and host immune response against the bacterial agent itself, have been addressed previously or at least have been significantly lessened. Combination therapies with Salmonellamediated therapy and other tumor therapies enhance the curative effects in a synergistic manner. This strategy is a hot topic for future research, but further improvement of the treatment through bioengineering and/or combinatorial approaches may significantly enhance its effectiveness in combating high-grade cancer malignancies.

\section{Acknowledgements}

This study was financially supported by the School of Pharmacy, Zanjan University of Medical Sciences, Zanjan, Iran.

\section{References}

Abrahams G.L., Hensel M. (2006) Manipulating cellular transport and immune responses: dynamic interactions between intracellular Salmonella enterica and its host cells. Cell. Microbiol. 8(5): 728-737.

Al-Ramadi B.K., Fernandez-Cabezudo M.J., El-Hasasna H., AlSalam S., Bashir G., Chouaib S. (2009) Potent anti-tumor activity of systemically-administered IL2-expressing Salmonella correlates with decreased angiogenesis and enhanced tumor apoptosis. Clin. Immunol. 130(1): 89-97.

Alaniz R.C., Cummings L.A., Bergman M.A., Rassoulian-Barrett S.L., Cookson B.T. (2006) Salmonella typhimurium coordinately regulates FliC location and reduces dendritic cell activation and antigen presentation to $C D 4+T$ cells. J. Immunol. 177(6): 3983-3993.

Anuforom O.N. (2015) The role of the immune response in the effectiveness of antibiotic treatment for antibiotic susceptible and antibiotic resistant bacteria. Univ. Birmingham.

Arrach N., Cheng P., Zhao M., Santiviago C.A., Hoffman R.M., McClelland M. (2010) High-throughput screening for Salmonella avirulent mutants that retain targeting of solid tumors. Cancer Res. 70(6): 2165-2170.

Arrach N., Zhao M., Porwollik S., Hoffman R.M., McClelland M. (2008) Salmonella promoters preferentially activated inside tumors. Cancer Res. 68(12): 4827-4832.

Avogadri F., Martinoli C., Petrovska L., Chiodoni C., Transidico P., Bronte V., Longhi R., Colombo M.P., Dougan G., Rescigno M. (2005) Cancer immunotherapy based on killing of Salmonella-infected tumor cells. Cancer Res. 65(9): 3920-3927.

Bahrami B., Hojjat-Farsangi M., Mohammadi H., Anvari E., Ghalamfarsa G., Yousefi M., Jadidi-Niaragh F. (2017) Nanoparticles and targeted drug delivery in cancer therapy. Immunol. Lett. 190: 64-83.

Bandura A. (2017) Psychotherapeutic treatment of cancer patients, Routledge.

Barbé S., Van Mellaert L., Theys J., Geukens N., Lammertyn E., Lambin P., Anné J. (2005) Secretory production of biologically active rat interleukin-2 by Clostridium acetobutylicum DSM792 as a tool for anti-tumor treatment. FEMS Microbiol. Lett. 246(1): 67-73.

Barker H.E., Paget J.T., Khan A.A., Harrington K.J. (2015) The tumour microenvironment after radiotherapy: mechanisms of resistance and recurrence. Nature Rev. Cancer 15(7): 409-425.

Barr T.A., Brown S., Mastroeni P., Gray D. (2009) B cell intrinsic MyD88 signals drive IFN- $\gamma$ production from $T$ cells and control switching to IgG2c. J. Immunol. 183(2): 1005-1012. 
Barrila J., Radtke A.L., Crabbé A., Sarker S.F., Herbst-Kralovetz M.M., Ott C.M., Nickerson C.A. (2010) Organotypic $3 D$ cell culture models: using the rotating wall vessel to study host-pathogen interactions. Nature Rev. Microbiol. 8(11): 791-801.

Berger E., Soldati R., Huebener N., Hohn O., Stermann A., Durmus T., Lobitz S., Zenclussen A.C., Christiansen H., Lode H.N. (2013) Salmonella SL7207 application is the most effective DNA vaccine delivery method for successful tumor eradication in a murine model for neuroblastoma. Cancer Lett. 331(2): 167-173.

Böhm W., Thoma S., Leithäuser F., Möller P., Schirmbeck R., Reimann J. (1998) T cell-mediated, IFN- - -facilitated rejection of murine B16 melanomas. J. Immunol. 161(2): 897-908.

Boucrot E., Henry T., Borg J.-P., Gorvel J.-P., Méresse S. (2005) The intracellular fate of Salmonella depends on the recruitment of kinesin. Science 308(5725): 1174-1178.

Boverhof D.R., David R.M. (2010) Nanomaterial characterization: considerations and needs for hazard assessment and safety evaluation. Analyt. Bioanal. Chem. 396(3): 953-961.

Bower M., Newlands E., Holden L., Short D., Brock C., Rustin G., Begent R., Bagshawe K. (1997) EMA/CO for high-risk gestational trophoblastic tumors: results from a cohort of 272 patients. J. Clin. Oncol. 15(9): 3168-3168.

Brigger I., Dubernet C., Couvreur P. (2012) Nanoparticles in cancer therapy and diagnosis. Adv. Drug Delivery Rev. 64: 24-36.

Broadway K.M., Suh S., Behkam B., Scharf B.E. (2017) Optimizing the restored chemotactic behavior of anticancer agent Salmonella enterica serovar Typhimurium VNP20009. J. Biotech. 251: 76-83.

Bruno V.M., Hannemann S., Lara-Tejero M., Flavell R.A., Kleinstein S.H., Galan J.E. (2009) Salmonella Typhimurium type III secretion effectors stimulate innate immune responses in cultured epithelial cells. PLoS Pathogens 5(8): e1000538.

Bueno S.M., Wozniak A., Leiva E.D., Riquelme S.A., Carreño L.J., Hardt W.D., Riedel C.A., Kalergis A.M. (2010) Salmonella pathogenicity island 1 differentially modulates bacterial entry to dendritic and non phagocytic cells. Immunology 130(2): 273-287.

Chen G., Wei D.P., Jia L.J.,Tang B., Shu L., Zhang K., Xu Y., Gao J., Huang X.F., Jiang W.H. (2009) Oral delivery of tumor targeting Salmonella exhibits promising therapeutic efficacy and low toxicity. Cancer Sci. 100(12): 2437-2443.

Chen J., Yang B., Cheng X., Qiao Y., Tang B., Chen G., Wei J., Liu X., Cheng W., Du P. (2012) Salmonella mediated tumor targeting TRAIL gene therapy significantly suppresses melanoma growth in mouse model. Cancer Sci. 103(2): 325-333.

Chen L.-M., Hobbie S., Galan J.E. (1996) Requirement of CDC42 for Salmonella-induced cytoskeletal and nuclear responses. Science 274(5295): 2115-2118.

Cheong I., Huang X., Bettegowda C., Diaz L.A., Kinzler K.W., Zhou S., Vogelstein B. (2006) A bacterial protein enhances the release and efficacy of liposomal cancer drugs. Science 314(5803): 1308-1311.

Chirullo B., Ammendola S., Leonardi L., Falcini R., Petrucci P., Pistoia C., Vendetti S., Battistoni A., Pasquali P. (2015) Attenuated mutant strain of Salmonella Typhimurium lacking the ZnuABC transporter contrasts tumor growth promoting anti-cancer immune response. Oncotarget 6(19): 17648.

Chorobik P., Czaplicki D., Ossysek K., Bereta J. (2013) Salmonella and cancer: from pathogens to therapeutics. Acta Biochim. Polon. 60(3): 285-297.

Clairmont C., Lee K., Pike J., Ittensohn M., Low K., Pawelek J., Bermudes D., Brecher S., Margitich D., Turnier J. (2000) Biodistribution and genetic stability of the novel antitumor agent VNP20009, a genetically modified strain of Salmonella typhimuvium. J. Infect. Dis. 181(6): 1996-2002.

Cossart P., Helenius A. (2014) Endocytosis of viruses and bacteria. Cold Spring Harbor Perspect. Biol. 6(8): a016972.

Coutermarsh-Ott S.L., Broadway K.M., Scharf B.E., Allen I.C. (2017) Effect of Salmonella enterica serovar Typhimurium VNP20009 and VNP20009 with restored chemotaxis on $4 T 1$ mouse mammary carcinoma progression. Oncotarget 8(20): 33601.

Dang L.H., Bettegowda C., Huso D.L., Kinzler K.W., Vogelstein B. (2001) Combination bacteriolytic therapy for the treatment of experimental tumors. Proc. Nat. Acad. Sci. 98(26): 15155-15160.

de Zoete M.R., Flavell R.A. (2013) Interactions between Nodlike receptors and intestinal bacteria. Front. Immun. 4: 462.

Efferth T., Sauerbrey A., Olbrich A., Gebhart E., Rauch P., Weber H.O., Hengstler J.G., Halatsch M.-E., Volm M., Tew K.D. (2003) Molecular modes of action of artesunate in tumor cell lines. Mol. Pharmacol. 64(2): 382-394.

Fahy O.L., Townley S.L., Coates N.J., Clark-Lewis I., McColl S.R. (2004) Control of Salmonella dissemination in vivo by macrophage inflammatory protein (MIP)-3 $\alpha / C C L 20$. Labor. Invest. 84(11): 1501-1511.

Felgner S., Kocijancic D., Frahm M., Weiss S. (2016) Bacteria in cancer therapy: renaissance of an old concept. Int. J. Microbiol. 2016: 8451728.

Feltis B., Miller J.S., Sahar D., Kim A., Saltzman D.A., Leonard A., Wells C.L., Sielaff T. (2002) Liver and circulating NK1. $1+C D 3-$ cells are increased in infection with attenuated Salmonella typhimurium and are associated with reduced tumor in murine liver cancer. J. Surg. Res. 107(1): 101-107.

Figueira R., Holden W. (2012) Functions of the Salmonella pathogenicity island 2 (SPI-2) type III secretion system effectors. Microbiology 158(5): 1147-1161.

Forbes N.S. (2010) Engineering the perfect (bacterial) cancer therapy. Nature Rev. Cancer 10(11): 785-794.

Forbes N.S., Munn L.L., Fukumura D., Jain R.K. (2003) Sparse initial entrapment of systemically injected Salmo- 
nella typhimurium leads to heterogeneous accumulation within tumors. Cancer Res. 63(17): 5188-5193.

Ganai S., Arenas R., Forbes N. (2009) Tumour-targeted delivery of TRAIL using Salmonella typhimurium enhances breast cancer survival in mice. British J. Cancer 101(10): 1683-1691.

Gharbavi M., Amani J., Kheiri-Manjili H., Danafar H., Sharafi A. (2018) Niosome: a promising nanocarrier for natural drug delivery through blood-brain barrier. Adv. Pharm. Pharm. Sci. 2018: 6847971.

Gharbavi M., Danafar H., Sharafi A. (2020) Microemulsion and bovine serum albumin nanoparticles as a novel hybrid nanocarrier system for efficient multifunctional drug delivery. J. Biomed. Mater. Res. A. https://doi.org/10.1002/ jbm.a.36935

Gharbavi M., Manjili H.K., Amani J., Sharafi A., Danafar H. (2019) In vivo and in vitro biocompatibility study of novel microemulsion hybridized with bovine serum albumin as nanocarrier for drug delivery. Heliyon 5(6): e01858.

Glenney G.W., Wiens G.D. (2007) Early diversification of the TNF superfamily in teleosts: genomic characterization and expression analysis. J. Immunol. 178(12): 7955-7973.

Goodman J., Walsh V. (2001) The story of taxol: nature and politics in the pursuit of an anti-cancer drug. Cambridge University Press.

Gracie J.A., Robertson S.E., McInnes I.B. (2003) Interleukin 18. J. Leukocyte Biol. 73(2): 213-224.

Grille S., Moreno M., Bascuas T., Marqués M., Muñoz N., Lens D., Chabalgoity J.A. (2014) Salmonella enterica serovar Typhimurium immunotherapy for $B$ cell lymphoma induces broad anti tumour immunity with therapeutic effect. Immunology 143(3): 428-437.

Guo H., Zhang J., Inal C. (2011) Targeting tumor gene by shRNA-expressing Salmonella-mediated RNAi. Gene Ther. 18(1): 95-105.

Hainfeld J.F., Dilmanian F.A., Slatkin D.N., Smilowitz H.M. (2008) Radiotherapy enhancement with gold nanoparticles. J. Pharm. Pharmacol. 60(8): 977-985.

Halici S., Zenk S.F., Jantsch J., Hensel M. (2008) Functional analysis of the Salmonella pathogenicity island 2-mediated inhibition of antigen presentation in dendritic cells. Infec. Immun. 76(11): 4924-4933.

Hare J.I., Lammers T., Ashford M.B., Puri S., Storm G., Barry S.T. (2017) Challenges and strategies in anti-cancer nanomedicine development: an industry perspective. Adv. Drug Delivery Rev. 108: 25-38.

Hartono S.B., Gu W., Kleitz F., Liu J., He L., Middelberg A.P., Yu C., Lu G.Q., Qiao S.Z. (2012) Poly-L-lysine functionalized large pore cubic mesostructured silica nanoparticles as biocompatible carriers for gene delivery. Acs Nano 6(3): 2104-2117.

Heimann D.M., Rosenberg S.A. (2003) Continuous intravenous administration of live genetically modified salmonella typhimurium in patients with metastatic melanoma. J. Immunother. 26(2): 179-180.

Helaine S., Cheverton A.M., Watson K.G., Faure L.M., Matthews S.A., Holden D.W. (2014) Internalization of Salmo- nella by macrophages induces formation of nonreplicating persisters. Science 343(6167): 204.

Hill A.B., Chen M., Chen C.-K., Pfeifer B.A., Jones C.H. (2016) Overcoming gene-delivery hurdles: physiological considerations for nonviral vectors. Trends Biotech. 34(2): 91-105.

Hoffman R.M., Zhao M. (2006) Whole-body imaging of bacterial infection and antibiotic response. Nature Prot. 1(6): 2988.

Hong E.-H., Chang S.-Y., Lee B.-R., Pyun A.-R., Kim J.-W., Kweon M.-N., Ko H.-J. (2013) Intratumoral injection of attenuated Salmonella vaccine can induce tumor microenvironmental shift from immune suppressive to immunogenic. Vaccine 31(10): 1377-1384.

Iyer P., Barreto S.G., Sahoo B., Chandrani P., Ramadwar M.R., Shrikhande S.V., Dutt A. (2016) Non-typhoidal Salmonella DNA traces in gallbladder cancer. Inf. Agents Cancer 11(1): 12.

Jahandideh S., Maghsood F., Ghahhari N.M., Lotfinia M., Mohammadi M., Johari B., Kadivar M. (2017) The effect of Trimetazidine and Diazoxide on immunomodulatory activity of human embryonic stem cell-derived mesenchymal stem cell secretome. Tissue Cell 49(5): 597-602.

Jarosz M., Jazowiecka-Rakus J., Cichoń T., Głowala-Kosińska M., Smolarczyk R., Smagur A., Malina S., Sochanik A., Szala S. (2013) Therapeutic antitumor potential of endoglin-based DNA vaccine combined with immunomodulatory agents. Gene Therapy 20(3): 262.

Jeong J.-H., Kim K., Lim D., Jeong K., Hong Y., Nguyen V.H., Kim T.-H., Ryu S., Lim J.-A., Kim J.I. (2014) Anti-tumoral effect of the mitochondrial target domain of Noxa delivered by an engineered Salmonella typhimurium. PloS one 9(1): e80050.

Jia H., Li Y., Zhao T., Li X., Hu J., Yin D., Guo B., Kopecko D.J., Zhao X., Zhang L. (2012) Antitumor effects of Stat3-siRNA and endostatin combined therapies, delivered by attenuated Salmonella, on orthotopically implanted hepatocarcinoma. Cancer Immun. Immunother. 61(11): 1977-1987.

Jiang S.-N., Park S.-H., Lee H.J., Zheng J.H., Kim H.-S., Bom H.-S., Hong Y., Szardenings M., Shin M.G., Kim S.-C. (2013) Engineering of bacteria for the visualization of targeted delivery of a cytolytic anticancer agent. Mol. Therapy 21(11): 1985-1995.

Jiang S.-N., Phan T.X., Nam T.-K., Nguyen V.H., Kim H.-S., Bom H.-S., Choy H.E., Hong Y., Min J.-J. (2010) Inhibition of tumor growth and metastasis by a combination of Escherichia coli-mediated cytolytic therapy and radiotherapy. Mol. Therapy 18(3): 635-642.

Jones B.D., Lee C.A., Falkow S. (1992) Invasion by Salmonella typhimurium is affected by the direction of flagellar rotation. Infec. Immun. 60(6): 2475-2480.

Juris S.J., Shao F., Dixon J.E. (2002) Yersinia effectors target mammalian signalling pathways. Cell. Microbiol. 4(4): 201-211.

Kaimala S., Mohamed Y.A., Nader N., Issac J., Elkord E., Chouaib S., Fernandez-Cabezudo M.J., al-Ramadi B.K. (2014) Salmonella-mediated tumor regression involves 
targeting of tumor myeloid suppressor cells causing a shift to M1-like phenotype and reduction in suppressive capacity. Cancer Immun. Immunother. 63(6): 587-599.

Kasinskas R.W., Forbes N.S. (2006) Salmonella typhimurium specifically chemotax and proliferate in heterogeneous tumor tissue in vitro. Biotech. Bioengin. 94(4): 710-721.

Kasinskas R.W., Forbes N.S. (2007) Salmonella typhimurium lacking ribose chemoreceptors localize in tumor quiescence and induce apoptosis. Cancer Res. 67(7): 3201-3209.

Kazmierczak R.A., Gentry B., Mumm T., Schatten H., Eisenstark A. (2016) Salmonella bacterial monotherapy reduces autochthonous prostate tumor burden in the TRAMP mouse model. PloS one 11(8): e0160926.

Kim J.-E., Phan T.X., Nguyen V.H., Dinh-Vu H.-V., Zheng J.H., Yun M., Park S.-G., Hong Y., Choy H.E., Szardenings M. (2015) Salmonella typhimurium suppresses tumor growth via the pro-inflammatory cytokine interleukin-1 $\beta$. Theranostics 5(12): 1328 .

Kimura H., Zhang L., Zhao M., Hayashi K., Tsuchiya H., Tomita K., Bouvet M., Wessels J., Hoffman R.M. (2010) Targeted therapy of spinal cord glioma with a genetically modified Salmonella typhimurium. Cell Prolifer. 43(1): 41-48.

King E.C., Jarvis E.P. (2007) Use of shear waves to measure Poisson's ratio in polar firn. J. Environ. Eng. Geophys. 12(1): 15-21.

Koshiol J., Wozniak A., Cook P., Adaniel C., Acevedo J., Azócar L., Hsing A.W., Roa J.C., Pasetti M.F., Miquel J.F. (2016) Salmonella enterica serovar Typhi and gallbladder cancer: a case-control study and meta analysis. Cancer Med. 5(11): 3310-3235.

Kural-Seyahi E., Fresko I., Seyahi N., Ozyazgan Y., Mat C., Hamuryudan V., Yurdakul S., Yazici H. (2003) The longterm mortality and morbidity of Behçet syndrome: a 2-decade outcome survey of 387 patients followed at a dedicated center. Medicine 82(1): 60-76.

Lee C.-H., Hsieh J.-L., Wu C.-L., Hsu H.-C., Shiau A.-L. (2011) $B$ cells are required for tumor-targeting Salmonella in host. Appl. Microbiol. Biotech. 92(6): 1251-1260.

Lee C.-H., Wu C.-L., Shiau A.-L. (2008) Toll-like receptor 4 mediates an antitumor host response induced by Salmonella choleraesuis. Clin. Cancer Res. 14(6): 1905-1912.

Lee C.-H., Wu C.-L., Tai Y.-S., Shiau A.-L. (2005) Systemic administration of attenuated Salmonella choleraesuis in combination with cisplatin for cancer therapy. Mol. Therapy 11(5): 707-716.

Lee C.H., Wu C.L., Shiau A.L. (2004) Endostatin gene therapy delivered by Salmonella choleraesuis in murine tumor models. J. Gene Med. 6(12): 1382-1393.

Lee C.H., Wu C.L., Shiau A.L. (2008) Salmonella choleraesuis as an anticancer agent in a syngeneic model of orthotopic hepatocellular carcinoma. Int. J. Cancer 122(4): 930-935.

Lee S.-H., Mizutani N., Mizutani M., Luo Y., Zhou H., Kaplan C., Kim S.-W., Xiang R., Reisfeld R.A. (2006) Endoglin (CD105) is a target for an oral DNA vaccine against breast cancer. Cancer Immun. Immunother. 55(12): 1565-1574.

Leschner S., Deyneko I.V., Lienenklaus S., Wolf K., Bloecker H., Bumann D., Loessner H., Weiss S. (2012) Identification of tumor-specific Salmonella Typhimurium promoters and their regulatory logic. Nucl. Acids Res. 40(7): 2984-2994.

Leschner S., Weiss S. (2010) Salmonella-allies in the fight against cancer. J. Mol. Med. 88(8): 763-773.

Leschner S., Westphal K., Dietrich N., Viegas N., Jablonska J., Lyszkiewicz M., Lienenklaus S., Falk W., Gekara N., Loessner H. (2009) Tumor invasion of Salmonella enterica serovar Typhimurium is accompanied by strong hemorrhage promoted by TNF- $\alpha$. PloS one 4(8): e6692.

Levine M., Herrington D., Murphy J., Morris J., Losonsky G., Tall B., Lindberg A., Svenson S., Baqar S., Edwards M. (1987) Safety, infectivity, immunogenicity, and in vivo stability of two attenuated auxotrophic mutant strains of Salmonella typhi, 541Ty and 543Ty, as live oral vaccines in humans. J. Clin. Invest. 79(3): 888-902.

Li B., He H., Zhang S., Zhao W., Li N., Shao R. (2012) Salmonella typhimurium strain SL7207 induces apoptosis and inhibits the growth of HepG2 hepatoma cells in vitro and in vivo. Acta Pharm. Sinica B 2(6): 562-568.

Li Z., Yin P.-H., Yang S.-S., Li Q.-Y., Chang T., Fang L., Shi L.X., Fang G.-E. (2013) Recombinant attenuated Salmonella typhimurium carrying a plasmid co-expressing ENDOVEGI151 and survivin siRNA inhibits the growth of breast cancer in vivo. Mol. Med. Rep. 7(4): 1215-1222.

Lin C.-S., Kao S.-H., Chen Y.-C., Li C.-H., Hsieh Y.-T., Yang S.C., Wu C.-J., Lee R.-P., Liao K.-W. (2012) Enhancement of anti-murine colon cancer immunity by fusion of a SARS fragment to a low-immunogenic carcinoembryonic antigen. Biol. Proced. online 14(1): 2.

Liu S., Xu X., Zeng X., Li L., Chen Q., Li J. (2014) Tumor targeting bacterial therapy: a potential treatment for oral cancer. Oncol. Lett. 8(6): 2359-2366.

Loeffler M., Le'Negrate G., Krajewska M., Reed J.C. (2007) Attenuated Salmonella engineered to produce human cytokine LIGHT inhibit tumor growth. Proc. Nat. Acad. Sci. 104(31): 12879-12883.

Loeffler M., Le'Negrate G., Krajewska M., Reed J.C. (2008) IL-18-producing Salmonella inhibit tumor growth. Cancer Gene Therapy 15(12): 787-794.

Loeffler M., Le'Negrate G., Krajewska M., Reed J.C. (2009) Salmonella typhimurium engineered to produce CCL21 inhibit tumor growth. CancerImmun.Immunother. 58(5): 769-775.

Lurain J.R., Nejad B. (2005) Secondary chemotherapy for high-risk gestational trophoblastic neoplasia. Gyn. Oncol. 97(2): 618-623.

Lushbaugh C., Casarett G.W. (1976) The effects of gonadal irradiation in clinical radiation therapy: a review. Cancer 37(S2): 1111-1120.

Maaser C., Housley M.P., Iimura M., Smith J.R., Vallance B.A., Finlay B.B., Schreiber J.R., Varki N.M., Kagnoff M.F., Eckmann L. (2004) Clearance of Citrobacter rodentium requires $B$ cells but not secretory immunoglobulin A (IgA) or IgM antibodies. Infec. Immunity 72(6): 3315-3324.

Maeda H. (2012) Macromolecular therapeutics in cancer treatment: the EPR effect and beyond. J. Control. Rel. 164(2): 138-144. 
Maeda H., Wu J., Sawa T., Matsumura Y., Hori K. (2000) Tumor vascular permeability and the EPR effect in macromolecular therapeutics: a review. J. Control. Rel. 65(1-2): 271-284.

Maekawa S., Iwasaki A., Shirakusa T., Kawakami T., Yanagisawa J., Tanaka T., Shibaguchi H., Kinugasa T., Kuroki M., Kuroki M. (2008) Association between the expression of chemokine receptors CCR7 and CXCR3, and lymph node metastatic potential in lung adenocarcinoma. Oncol. Rep. 19(6): 1461-1468.

Manuel E.R., Blache C.A., Paquette R., Kaltcheva T.I. Ishizaki, H., Ellenhorn J.D., Hensel M., Metelitsa L., Diamond D.J. (2011) Enhancement of cancer vaccine therapy by systemic delivery of a tumor-targeting Salmonella-based STAT3 shRNA suppresses the growth of established melanoma tumors. Cancer Res. 71(12): 4183-4191.

Marcus A., Gowen B.G., Thompson T.W., Iannello A., Ardolino M., Deng W., Wang L., Shifrin N., Raulet D.H. (2014) Recognition of tumors by the innate immune system and natural killer cells. Adv. Immunol. 122: 91-128.

Maybeno M., Redeker A., Welten S.P., Peters B., Loughhead S.M., Schoenberger S.P., Sette A., Arens R. (2012) Polyfunctional $C D 4+T$ cell responses to immunodominant epitopes correlate with disease activity of virulent Salmonella. PloS one 7(8): e43481.

Mazurkiewicz P., Thomas J., Thompson J.A., Liu M., Arbibe L., Sansonetti P., Holden D.W. (2008) SpvC is a Salmonella effector with phosphothreonine lyase activity on host mitogen activated protein kinases. Mol. Microbiol. 67(6): 1371-1383.

McCarthy E.F. (2006) The toxins of William B. Coley and the treatment of bone and soft-tissue sarcomas. Iowa Orthop. J. 26: 154 .

Melmed S., Colao A., Barkan A., Molitch M., Grossman A., Kleinberg D., Clemmons D., Chanson P., Laws E., Schlechte J. (2009) Guidelines for acromegaly management: an update. J. Clin. Endocrinol. Metab. 94(5): 1509-1517.

Mercado-Lubo R., Zhang Y., Zhao L., Rossi K., Wu X., Zou Y., Castillo A., Leonard J., Bortell R., Greiner D. L. (2016) $A$ Salmonella nanoparticle mimic overcomes multidrug resistance in tumours. Nature Commun. 7: 12225.

Mijouin L., Rosselin M., Bottreau E., Pizarro-Cerda J., Cossart P., Velge P., Wiedemann A. (2012) Salmonella enteritidis Rck-mediated invasion requires activation of Rac1, which is dependent on the class I PI 3-kinases-Akt signaling pathway. FASEB J. 26(4): 1569-1581.

Minton N.P. (2003) Clostridia in cancer therapy. Nature Rev. Microbiol. 1(3): 237-242.

Mittrücker H.W., Kaufmann S.H. (2000) Immune response to infection with Salmonella typhimurium in mice. J. Leukocyte Biol. 67(4): 457-463.

Momiyama M., Zhao M., Kimura H., Tran B., Chishima T., Bouvet M., Endo I., Hoffman R.M. (2012) Inhibition and eradication of human glioma with tumor-targeting Salmonella typhimurium in an orthotopic nude-mouse model. Cell Cycle 11(3): 628-632.
Morrissey D., O’Sullivan G.C., Tangney M. (2010) Tumour targeting with systemically administered bacteria. Curr. Gene Therapy 10(1): 3-14.

Mukherjee B., Chakraborty S., Mondal L., Satapathy B.S., Sengupta S., Dutta L., Choudhury A., Mandal D. (2016) Multifunctional drug nanocarriers facilitate more specific entry of therapeutic payload into tumors and control multiple drug resistance in cancer. Nanobiomat. Cancer Therapy, Elsevier: 203-251.

Nemunaitis J., Cunningham C., Senzer N., Kuhn J., Cramm J., Litz C., Cavagnolo R., Cahill A., Clairmont C., Sznol M. (2003) Pilot trial of genetically modified, attenuated Salmonella expressing the $E$. coli cytosine deaminase gene in refractory cancer patients. Cancer Gene Therapy 10(10): 737.

Nguyen V.H., Kim H.-S., Ha J.-M., Hong Y., Choy H.E., Min J.J. (2010) Genetically engineered Salmonella typhimurium as an imageable therapeutic probe for cancer. Cancer Res. 70(1): 18-23.

Nguyen V.H., Min J.-J. (2017) Salmonella-mediated cancer therapy: roles and potential. Nucl. Med. Mol. Imag. 51(2): 118-126.

Nuyts S., Van Mellaert L., Theys J., Landuyt W., Lambin P., Anné J. (2001) The use of radiation-induced bacterial promoters in anaerobic conditions: a means to control gene expression in clostridium-mediated therapy for cancer. Radiat. Res. 155(5): 716-723.

Oppong G.O., Rapsinski G.J., Newman T.N., Nishimori J.H., Biesecker S.G., Tükel Ç. (2013) Epithelial cells augment barrier function via activation of the Toll-like receptor 2/phosphatidylinositol 3-kinase pathway upon recognition of Salmonella enterica serovar Typhimurium curli fibrils in the gut. Infec. Immun. 81(2): 478-486.

Patriciu A., Petrisor D., Muntener M., Mazilu D., Schar M., Stoianovici D. (2007) Automatic brachytherapy seed placement under MRI guidance. IEEE Trans. Biomed. Eng. 54(8): 1499-1506.

Paulides M.M., Stauffer P.R., Neufeld E., Maccarini P.F., Kyriakou A., Canters R.A., Diederich C.J., Bakker J.F., Van Rhoon G.C. (2013) Simulation techniques in hyperthermia treatment planning. Int. J. Hypertherm. 29(4): 346-357.

Pawelek J.M., Low K.B., Bermudes D. (1997) Tumor-targeted Salmonella as a novel anticancer vector. Cancer Res. 57(20): 4537-4544.

Pawelek J.M., Low K.B., Bermudes D. (2003) Bacteria as tumour-targeting vectors. Lancet Oncol. 4(9): 548-556.

Perez-Lopez A., Rosales-Reyes R., Alpuche-Aranda C.M., OrtizNavarrete V. (2013) Salmonella downregulates Nod-like receptor family $C A R D$ domain containing protein $4 \mathrm{ex}$ pression to promote its survival in $B$ cells by preventing inflammasome activation and cell death. J. Immunol. 190(3): 1201-1209.

Perry M.C., Eaton W.L., Propert K.J., Ware J.H., Zimmer B., Chahinian A.P., Skarin A., Carey R.W., Kreisman H., Faulkner C. (1987) Chemotherapy with or without radiation therapy in limited small-cell carcinoma of the lung. New Engl. J. Med. 316(15): 912-918. 
Qian B.-J., Yan F., Li N., Liu Q.-L., Lin Y.-H., Liu C.-M., Luo Y.P., Guo F., Li H.-Z. (2011) MTDH/AEG-1-based DNA vaccine suppresses lung metastasis and enhances chemosensitivity to doxorubicin in breast cancer. Cancer Immun. Immunother. 60(6): 883-893.

Qin Z., Blankenstein T. (2000) CD4+ T cell-mediated tumor rejection involves inhibition of angiogenesis that is dependent on IFNy receptor expression by nonhematopoietic cells. Immunity 12(6): 677-686.

Raupach B., Peuschel S.-K., Monack D.M., Zychlinsky A. (2006) Caspase-1-mediated activation of interleukin-1 $\beta$ (IL-1 $\beta$ ) and IL-18 contributes to innate immune defenses against Salmonella enterica serovar Typhimurium infection. Inf. Immun. 74(8): 4922-4926.

Ravi M., Ramesh A., Pattabhi A. (2017) Contributions of $3 D$ cell cultures for cancer research. J. Cell. Physiol. 232(10): 2679-2697.

Resnick E.S., Moshier E.L., Godbold J.H., Cunningham-Rundles C. (2012) Morbidity and mortality in common variable immune deficiency over 4 decades. Blood J. American Soc. Hematol. 119(7): 1650-1657.

Roider E., Jellbauer S., Köhn B., Berchtold C., Partilla M., Busch D.H., Rüssmann H., Panthel K. (2011) Invasion and destruction of a murine fibrosarcoma by Salmonella-induced effector CD8 $T$ cells as a therapeutic intervention against cancer. Cancer Immun. Immunother. 60(3): 371-380.

Rosenberg S.A., Spiess P.J., Kleiner D.E. (2002) Antitumor effects in mice of the intravenous injection of attenuated Salmonella typhimurium. J. Immun. 25(3): 218.

Ryan R.M., Green J., Lewis C.E. (2006) Use of bacteria in anti cancer therapies. Bioessays 28(1): 84-94.

Sahoo S., Parveen S., Panda J. (2007) The present and future of nanotechnology in human health care. Nanomed. Nanotech. Biol. Med. 3(1): 20-31.

Salcedo S.P., Holden D.W. (2003) SseG, a virulence protein that targets Salmonella to the Golgi network. EMBO J. 22(19): 5003-5014.

Schlumberger M.C., Hardt W.-D. (2006) Salmonella type III secretion effectors: pulling the host cell's strings. Curr. Opinion Microbiol. 9(1): 46-54.

Sfondrini L., Rossini A., Besusso D., Merlo A., Tagliabue E., Mčnard S., Balsari A. (2006) Antitumor activity of the TLR-5 ligand flagellin in mouse models of cancer. J. Immun. 176(11): 6624-6630.

Shi L., Yu B., Cai C.-H., Huang W., Zheng B.-J., Smith D. K., Huang J.-D. (2016) Combined prokaryotic-eukaryotic delivery and expression of therapeutic factors through a primed autocatalytic positive-feedback loop. J. Control. Rel. 222: 130-140.

Soghomonyan S.A., Doubrovin M., Pike J., Luo X., Ittensohn M., Runyan J.D., Balatoni J., Finn R., Tjuvajev J.G., Blasberg R. (2005) Positron emission tomography (PET) imaging of tumor-localized Salmonella expressing HSV1-TK. Cancer Gne Therapy 12(1): 101-108.

Sorenson B.S., Banton K.L., Frykman N.L., Leonard A.S., Saltzman D.A. (2008) Attenuated Salmonella typhimurium with interleukin 2 gene prevents the establishment of pulmonary metastases in a model of osteosarcoma. J. Pediatr. Surg. 43(6): 1153-1158.

Steele-Mortimer O. (2008) The Salmonella-containing vacuolemoving with the times. Curr. Opin. Microbiol. 11(1): 38-45.

Steele Mortimer O. (2011) Exploitation of the ubiquitin system by invading bacteria. Traffic 12(2): 162-169.

Stender S., Friebel A., Linder S., Rohde M., Mirold S., Hardt W.D. (2000) Identification of SopE2 from Salmonella typhimurium, a conserved guanine nucleotide exchange factor for Cdc42 of the host cell. Mol. Microbiol. 36(6): 1206-1221.

Sznol M., Lin S.L., Bermudes D., Zheng L.-M., King I. (2000) Use of preferentially replicating bacteria for the treatment of cancer. J. Clin. Invest. 105(8): 1027-1030.

Taniguchi S.I., Fujimori M., Sasaki T., Tsutsui H., Shimatani Y., Seki K., Amano J. (2010) Targeting solid tumors with non pathogenic obligate anaerobic bacteria. Cancer Sci. 101(9): 1925-1932.

Thamm D.H., Kurzman I.D., King I., Li Z., Sznol M., Dubielzig R.R., Vail D.M., MacEwen E.G. (2005) Systemic administration of an attenuated, tumor-targeting Salmonella typhimurium to dogs with spontaneous neoplasia: phase I evaluation. Clin. Cancer Res. 11(13): 4827-4834.

Theys J., Pennington O., Dubois L., Anlezark G., Vaughan T., Mengesha A., Landuyt, J. Anné W., Burke P., Durre P. (2006) Repeated cycles of Clostridium-directed enzyme prodrug therapy result in sustained antitumour effects in vivo. Brit. J. Cancer 95(9): 1212-1219.

Toso J.F., Gill V.J., Hwu P., Marincola F.M., Restifo N.P., Schwartzentruber D.J., Sherry R.M., Topalian S.L., Yang J.C., Stock F. (2002) Phase I study of the intravenous administration of attenuated Salmonella typhimurium to patients with metastatic melanoma. J. Clin. Oncol. 20(1): 142.

Urashima M., Suzuki H., Yuza Y., Akiyama M., Ohno N., Eto Y. (2000) An oral CD40 ligand gene therapy against lymphoma using attenuated Salmonella typhimurium. Blood, J. Amer. Soc. Hematol. 95(4): 1258-1263.

Vagholkar, K., Pawanarkar A., Iyengar M., Vagholkar S. (2016) Chronic Salmonella typhi carrier state: a precursor to gall bladder cancer. Inter. Surg. J. 3(2): 464-467.

Van Mellaert L., Barbé S., Anné J. (2006) Clostridium spores as anti-tumour agents. Trends Microbiol. 14(4): 190-196.

Velge P., Wiedemann A., Rosselin M., Abed N., Boumart Z., Chausse A., Grépinet O., Namdari F., Roche S., Rossignol A. (2012) Multiplicity of $S$ almonella entry mechanisms, a new paradigm for $S$ almonella pathogenesis. Microbiologyopen 1(3): 243-258.

Wang Y., Chen J., Tang B., Zhang X., Hua Z.-C. (2013) $S y-$ stemic administration of attenuated Salmonella typhimurium in combination with interleukin-21 for cancer therapy. Mol. Clin. Oncol. 1(3): 461-465.

Wei M.Q., Ellem K.A., Dunn P., West M.J., Bai C.X., Vogelstein B. (2007) Facultative or obligate anaerobic bacteria have the potential for multimodality therapy of solid tumours. Eur. J. Cancer 43(3): 490-496. 
Weiss J.M., Subleski J.J., Wigginton J.M., Wiltrout R.H. (2007) Immunotherapy of cancer by IL-12-based cytokine combinations. Expert Opin. Biol. Therapy 7(11): 1705-1721.

Westphal K., Leschner S., Jablonska J., Loessner H., Weiss S. (2008) Containment of tumor-colonizing bacteria by host neutrophils. Cancer Res. 68(8): 2952-2960.

Wiedemann A., Rosselin M., Mijouin L., Bottreau E., Velge P. (2012) Involvement of $c$-Src tyrosine kinase upstream of class I phosphatidylinositol (PI) 3-kinases in Salmonella Enteritidis Rck protein-mediated invasion. J. Biol. Chem. 287(37): 31148-31154.

Wu Q., Yang Z., Nie Y., Shi Y., Fan D. (2014) Multi-drug resistance in cancer chemotherapeutics: mechanisms and lab approaches. Cancer Lett. 347(2): 159-166.

Xia T., Kovochich M., Brant J., Hotze M., Sempf J., Oberley T., Sioutas C., Yeh J.I., Wiesner M.R., Nel A.E. (2006) Comparison of the abilities of ambient and manufactured nanoparticles to induce cellular toxicity according to an oxidative stress paradigm. Nano Lett. 6(8): 1794-1807.

Xiang R., Mizutani N., Luo Y., Chiodoni C., Zhou H., Mizutani M., Ba Y., Becker J.C., Reisfeld R.A. (2005) A DNA vaccine targeting survivin combines apoptosis with suppression of angiogenesis in lung tumor eradication. Cancer Res. 65(2): 553-561.

Xiong G., Husseiny M.I., Song L., Erdreich Epstein A., Shackleford G.M., Seeger R.C., Jäckel D., Hensel M., Metelitsa L.S. (2010) Novel cancer vaccine based on genes of Salmonella pathogenicity island 2. Int. J. Cancer 126(11): 2622-2634.

Xu J., Liu X.S., Zhou S.-F., Wei M.Q. (2009) Combination of immunotherapy with anaerobic bacteria for immunogene therapy of solid tumours. Gene Ther. Mol. Biol. 13(1): $36-52$.

Xu X., Hegazy W.A., Guo L., Gao X., Courtney A.N., Kurbanov S., Liu D., Tian G., Manuel E.R., Diamond D.J. (2014) Effective cancer vaccine platform based on attenuated salmonella and a type III secretion system. Cancer Res. 74(21): 6260-6270.

Yan W., Khan M.K., Wu X., Simone C.B. (2020) Spatially fractionated radiation therapy: History, present and the future. Clinical Transl. Radiat. Oncol. 20: 30.

Yang C.-J., Chang W.-W., Lin S.-T., Chen M.-C., Lee C.-H. (2018) Salmonella overcomes drug resistance in tumor through P-glycoprotein downregulation. Int. J. Med. Sci. 15(6): 574.

Yang N., Zhu X., Chen L., Li S., Ren D. (2008) Oral administration of attenuated $S$. typhimurium carrying shRNAexpressing vectors as a cancer therapeutic. Cancer Biol. Therapy 7(1): 145-151.
Yano S., Zhang Y., Zhao M., Hiroshima Y., Miwa S., Uehara F., Kishimoto H., Tazawa H., Bouvet M., Fujiwara T. (2014) Tumor-targeting Salmonella typhimurium A1-R decoys quiescent cancer cells to cycle as visualized by FUCCI imaging and become sensitive to chemotherapy. Cell Cycle 13(24): 3958-3963.

Ye J., Li L., Zhang Y., Zhang X., Ren D., Chen W. (2013) Recombinant salmonella-based $4-1 B B L$ vaccine enhances $T$ cell immunity and inhibits the development of colorectal cancer in rats: in vivo effects of vaccine containing 4-1BBL. J. Biomed. Sci. 20(1): 8.

Yoon W., Choi J.H., Kim S., Park Y.K. (2014) Engineered Salmonella typhimurium expressing E7 fusion protein, derived from human papillomavirus, inhibits tumor growth in cervical tumor-bearing mice. Biotech. Lett. 36(2): 349-356.

Yu B., Shi L., Zhang B.Z., Zhang K., Peng X., Niu H.B., Qu J.L. (2015) Obligate anaerobic Salmonella typhimurium strain YB1 treatment on xenograft tumor in immunocompetent mouse model. Oncol. Lett. 10(2): 1069-1074.

Yu B., Yang M., Shi L., Yao Y., Jiang Q., Li X., Tang L.-H., Zheng B.-J., Yuen K.-Y., Smith D.K. (2012) Explicit hypoxia targeting with tumor suppression by creating an "obligate" anaerobic Salmonella Typhimurium strain. Sci. Rep. 2: 436.

Zhang L., Ao L.G, Zhao L., Guo B., Ji K., Tian Y., Wang J., Yu H., Hu J., Kalvakolanu D.V. (2007) Intratumoral delivery and suppression of prostate tumor growth by attenuated Salmonella enterica serovar typhimurium carrying plasmidbased small interfering RNAs. Cancer Res. 67(12): 5859-5864.

Zhao M., Geller J., Ma H., Yang M., Penman S., Hoffman R.M. (2007) Monotherapy with a tumor-targeting mutant of Salmonella typhimurium cures orthotopic metastatic mouse models of human prostate cancer. Proceedings of the National Academy of Sciences 104(24): 10170-10174.

Zhao M., Yang M., Li X.-M., Jiang P., Baranov E., Li S., Xu M., Penman S., Hoffman R.M. (2005) Tumor-targeting bacterial therapy with amino acid auxotrophs of GFP-expressing Salmonella typhimurium. Proc. Nat. Acad. Sci 102(3): 755-760.

Zhao M., Yang M., Ma H., Li X., Tan X., Li S., Yang Z., Hoffman R.M. (2006) Targeted therapy with a Salmonella typhimurium leucine-arginine auxotroph cures orthotopic human breast tumors in nude mice. Cancer Res. 66(15): 7647-7652. 